Original Research Paper

\title{
Perbedaan Prestasi Belajar Pada Pembelajaran Fisika dengan Menggunakan Laboratorium Real dan Virtual Ditinjau dari Sikap Ilmiah Siswa
}

\author{
Sri Murni ${ }^{1 *}$, Susilawati $^{2}$, Nyoman Sridana $^{3}$ \\ ${ }^{1}$ Sekolah Menengah Atas Negeri 1 Mataram. \\ ${ }^{2}$ Program Studi Magister Pendidikan IPA, Universitas Mataram \\ ${ }^{3}$ Program Studi Pendidikan Matematika, Universitas Mataram
}

*Corresponding Author:

Sri Murni, Sekolah

Menengah Atas Negeri 1

Mataram, Indonesia;

Email: srifis92@gmail.com

\begin{abstract}
Abstrak: Penelitian ini bertujuan untuk mengetahui ada tidaknya (1) perbedaan prestasi belajar antara penggunaan laboratorium real dan laboratorium gabungan real virtual; (2) perbedaan prestasi belajar antara siswa yang memiliki sikap ilmiah tinggi dan siswa yang memiliki sikap ilmiah rendah; (3) pengaruh interaksi antara penggunaan laboratorium dengan sikap ilmiah terhadap prestasi belajar siswa. Prestasi belajar yang dimaksud adalah prestasi belajar kognitif. Penentuan sampel dengan teknik random sampling. Sampel penelitian diambil 4 kelas dari 5 kelas $\mathrm{X}$ SMAN 1 Labuapi berjumlah 102 siswa, yang terbagi menjadi dua kelompok eksperimen, kelompok pertama penggunaan laboratorium real dan kelompok kedua penggunaan laboratorium gabungan real virtual. Pengambilan data dilakukan dengan tehnik tes prestasi kognitif dan sikap ilmiah dengan angket. Penelitian eksperimen ini menggunakan desain faktorial $2 \times 2$. Data dianalisis dengan menggunakan teknik analisis varians (ANAVA) dua jalan dengan bantuan program SPSS 16,0 for windows. Hasil analisis data pada taraf signifikan (probabilitas kurang 0,05) menunjukkan bahwa: (1) nilai probabilitias penggunaan laboratorium prestasi kognitif 0,005; (2) Sikap ilmiah nilai probabilitas prestasi kognitif 0,000, (3) pengaruh interaksi penggunaan laboratorium degan sikap ilmiah nilai probabilitas prestasi kognitif 0,565. Kesimpulan: (1) ada perbedaan prestasi belajar kognitif antara penggunaan laboratorium real dan laboratorium gabungan real virtual; (2) ada perbedaan prestasi belajar kognitif antara siswa yang memiliki sikap ilmiah tinggi dan siswa yang memiliki sikap ilmiah rendah; (3) tidak ada pengaruh interaksi antara penggunaan laboratorium dengan sikap ilmiah terhadap prestasi belajar siswa.
\end{abstract}

Kata Kunci: Laboratorium real dan vitual, Sikap ilmiah, Prestasi belajar

\section{Pendahuluan}

Mata pelajaran Fisika di Sekolah ditujukan
untuk mendidik siswa agar mampu
mengembangkan observasi dan eksperimentasi
serta berpikir taat asas. Hal ini didasari oleh tujuan
Fisika, yakni mengamati, memahami, dan
memanfaatkan gejala-gejala alam yang melibatkan
zat (materi) dan energi. Kemampuan observasi dan
eksperimentasi ini lebih ditekankan pada melatih
kemampuan berpikir eksperimental yang mencakup
tatalaksana percobaan dengan mengenal peralatan
yang digunakan dalam pengukuran baik di dalam
laboratorium maupun di alam sekitar kehidupan
siswa. Kemampuan berpikir dilatihkan melalui

pengelolaan data untuk selanjutnya dengan menggunakan perangkat matematis dibangun konsep, prinsip, hukum dan teori (Depdiknas, 2008).

Hakekat dari pembelajaran sains mencakup kemampuan proses, produk dan sikap yang diharapkan dari peserta didik. Menurut Fatika (1987), sains adalah suatu kumpulan pengetahuan yang tersusun secara sistematik yang dalam penggunaannya secara umum terlintas pada gejalagejala alam. Produk sains adalah semua pengetahuan tentang gejala alam yang telah dikumpulkan melalui observasi. Produk sains berupa fakta, hukum, dan teori. Proses sains atau metode ilmiah adalah cara kerja yang dilakukan 
untuk mencapai hasil-hasil pengetahuan alam. Nilai dan Sikap adalah semua tingkah laku yang diperlukan selama melakukan proses sains, sehingga tercapai hasil-hasil sains. Selama melakukan metode ilmiah proses observasi dan eksperimen digunakan sikap ilmiah seperti: jujur, kritis, obyektif, rasional, terbuka, komunikatif dan sebagainya, agar tercapai ilmu pengetahauan yang benar.

Menurut Bruner belajar tidak untuk mengubah tingkah laku seseorang semata, tetapi juga mengubah kurikulum sekolah menjadi sedemikian rupa sehingga siswa dapat belajar lebih banyak dan mudah (Slameto, 2010). Bruner juga mengatakan bahwa untuk meningkatkan proses belajar diperlukan lingkungan yang dinamakan "discovery learning environment", ialah lingkungan dimana siswa dapat melakukan eksplorasi, penemuan-penemuan baru yang belum dikenal atau pengertian yang mirip dengan yang sudah diketahui. Oleh sebab itu Bruner mempunyai pendapat, alangkah baiknya bila sekolah dapat menyediakan kesempatan bagi siswa untuk maju dengan cepat sesuai kemampuan siswa dalam mata pelajaran tertentu.

Gagne (Slameto, 2010), mendefinisikan belajar menjadi dua yaitu: (1) Belajar adalah suatu proses untuk memperoleh motivasi dalam pengetahuan, ketrampilan, kebiasaan, dan tingkah laku; (2) Belajar adalah penguasan pengetahuan atau ketrampilan yang diperoleh dari instruksi. Gagne mengatakan pula bahwa segala sesuatu yang dipelajari oleh manusia dapat dibagi menjadi 5 kategori, yang disebut "The domains of learning", yaitu ketrampilan motorik, informasi verbal, kemampuan intelektual, strategi kognitf, dan sikap.

Teori belajar menurut pandangan konstruktivis menyatakan bahwa siswa tidak menerima begitu saja pengetahuan tetapi siswa secara aktif membangun pengetahuannya dengan cara terus menerus mengasimilasi dan mengakomodasi informasi baru, yang terpenting dalam proses pembelajaran menurut teori konstruktivisme siswalah yang harus mendapatkan penekanan. Merekalah yang harus aktif mengembangkan pengetahuannya, bukan pembelajar atau orang lain. Penekanan belajar siswa secara aktif ini perlu dikembangkan. Kreativitas dan keaktifan siswa akan membantu mereka untuk berdiri sendiri dalam kehidupan kognitif siswa. Belajar lebih diarahkan pada experimental learning yaitu merupakan adaptasi kemanusiaan berdasarkan pengalaman konkrit di laboratorium, diskusi dengan teman sekelas, yang kemudian dikontemplasikan dan dijadikan ide dan pengembangan konsep baru. Beberapa hal yang mendapat perhatian pembelajaran konstruktivistik, yaitu: (1) mengutamakan pembelajaran yang bersifat nyata dalam kontek yang relevan, (2) mengutamakan proses, (3) menanamkan pembelajaran dalam konteks pengalaman sosial, (4) pembelajaran dilakukan dalam upaya mengkonstruksi pengalaman.

Di dalam kegiatan mempelajari fisika dimungkinkan adanya pengamatan, penelitian dan percobaan pada gejala alam kemudian diambil kesimpulan. Dari kesimpulan itu disusun konsep, teori atau hukum yang akan dipakai sebagai dasar untuk melakukan kegiatan eksperimen lebih lanjut. Langkah kerja yang dipakai untuk menemukan fakta, teori, hukum, prinsip, dan konsep yang ditempuh biasa disebut metode ilmiah. Adapun metode pengajaran yang menyangkut hakekat fisika tersebut adalah eksperimen, penemuan, demonstrasi, kerja kelompok, diskusi dan sebagainya. Fenomena eksperimen yang dimaksud adalah penggunaan laboratorium baik real maupun virtual atau gabungan real virtual dalam proses pembelajaran fisika.

Laboratorium real adalah laboratorium tempat khusus yang dilengkapi dengan peralatan atau bahan-bahan nyata untuk kepentingan pelaksanaan eksperimen baik fisika, kimia, atau biologi. Sedangkan laboratorium virtual adalah suatu simulasi atau percobaan yang dilakukan di komputer untuk menyajikan fenomena alam yang memiliki peranan penting di dalam proses pembelajaran sains. Laboratorium ini berupa software yang tentu saja dijalankan oleh sebuah computer.

Tujuan pembelajaran dengan metode eksperimen adalah agar siswa mencari dan menemukan sendiri berbagai jawaban atas persoalan-persoalan yang dihadapinya dengan mengadakan percobaan sendiri, siswa terlatih dalam berpikir dan bersikap ilmiah, dan dengan eksperimen siswa menemukan bukti kebenaran dari teori/konsep sesuatu yang sedang dipelajari (Roestiyah, 1991).

Sikap ilmiah adalah perasaan positip atau negatif terhadap nilai-nilai keilmuan atau "Scientific attitude", yang meliputi sikap kritis, 
rasional, logis, obyektif, terbuka, menjunjung kebenaran, dan pengabdian universal.

Banyak kendala yang dialami oleh guru dalam melakukan praktikum di laboratorium sehingga guru tersebut tidak mengajak siswa untuk melakukan praktikum, diantaranya adalah melakukan eksperimen di laboratorium membutuhkan waktu yang lama, tidak ada laboran sehingga guru kerja sendirian, tidak seimbangnta muatan materi pada SK/KD dengan jumlah jam yang tersedia, dan tidak seimbangnya antara jumlah siswa dengan alat-alat laboratorium real yang ada sehingga pembelajaran kurang afektif dan efisien.

Berdasarkan latar belakang tersebut, dilakukan penelitian dengan rumusan masalah "apakah ada perbedaan prestasi belajar kognitif siswa antara penggunaan laboratoriun real dan laboratoriun gabungan real virtual ditinjau dari sikap ilmiah siswa?"dengan hipotesis yang berbunyi: 1) Ada perbedaan prestasi belajar kognitif siswa antara penggunaan laboratorium real dan laboratorium gabungan real virtual pada pembelajaran fisika, 2) ada perbedaan prestasi belajar kognitif antara siswa yang memiliki sikap ilmiah tinggi dan siswa yang memiliki sikap ilmiah rendah pada pembelajaran fisika, dan 3) ada pengaruh interaksi antara penggunaan laboratorium dengan sikap ilmiah terhadap prestasi belajar kognitif siswa yang mengikuti pembelajaran fisika.

\section{Metode Pelaksanaan}

Penelitian ini dilakukan di SMA Negeri 1 Labuapi kelas X tahun pelajaran 2010/2011 dengan sampel sebanyak 102 siswa yang terbagi dalam 4 kelas. Penelitian dilakukan pada materi "Listrik Dinamis".

Penelitian ini merupakan penelitian eksperimen. Penelitian eksperimen dilakukan untuk menguji ada tidaknya perbedaan prestasi belajar kognitif siswa antara penggunaan laboratorium real dan laboratorium gabungan real virtual ditinjau dari sikap ilmiah siswa. Desain penelitian yang digunakan berupa "Factorial Design" yaitu faktorial $2 \times 2$ yang disajikan dalam bentuk bagan berikut:

\begin{tabular}{|l|l|l|l|}
\cline { 3 - 4 } \multicolumn{2}{c|}{} & \multicolumn{2}{|l|}{ Media Laboraorium $(\mathrm{A})$} \\
\cline { 3 - 4 } \multicolumn{2}{c|}{} & Real-Virtual $\left(\mathrm{A}_{1}\right)$ & Real $\left(\mathrm{A}_{2}\right)$ \\
\hline $\begin{array}{l}\text { Sikap } \\
\text { Ilmiah } \\
\text { Siswa (B) }\end{array}$ & Tinggi $\left(\mathrm{B}_{1}\right)$ & $\mathrm{A}_{1} \mathrm{~B}_{1}$ & $\mathrm{~A}_{2} \mathrm{~B}_{1}$ \\
\cline { 2 - 4 } & Rendah $\left(\mathrm{B}_{2}\right)$ & $\mathrm{A}_{1} \mathrm{~B}_{2}$ & $\mathrm{~A}_{2} \mathrm{~B}_{2}$ \\
\hline
\end{tabular}

Dengan:

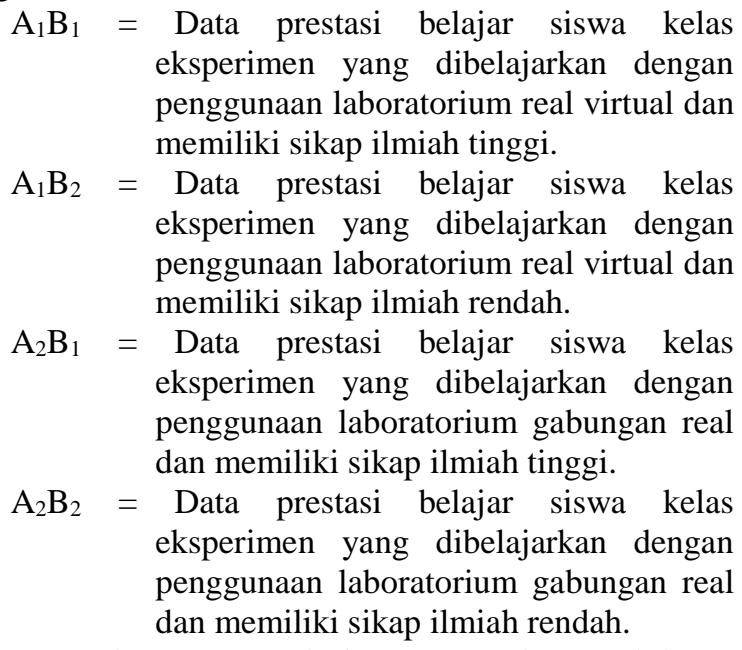

Untuk mengetahui pengaruh perlakuan terhadap prestasi belajar siswa dilakukan analisis dengan statistik "analisis varians (ANAVA) dua arah" menggunakan SPSS versi 16.0 pada taraf signifikan 0,05 .

\section{Hasil dan Pembahasan}

Setelah dilakukan uji prasyarat (uji normalitas dan homogenitas) data yang diperoleh dilakukan uji statistik yang dilakukan dengan menggunakan analisis varians. Hasil analisis dijelaskan seperti Tabel 1.

Tabel 1. Hasil Analisis Data Penelitian

\begin{tabular}{llllll}
\hline Source & Sum of Squares & df & F table & F & Sig. \\
\hline Laboratorium (Real - Gab Real Virtual) & 1082,916 & 1 & 3.96 & 8,398 & 0,005 \\
Sikap Ilmiah (Tinggi - Rendah) & 2079,568 & 1 & 3.96 & 16,126 & 0,000 \\
Laboratorium*Sikap ilmiah & 43,028 & 1 & 3.96 & 0,334 & 0,565 \\
\hline
\end{tabular}


Hasil analisis varians yang dilakukan terhadap nilai prestasi belajar kognitif pada perbedaan prestasi belajar kognitif siswa penggunaan laboratorium real dan gabungan real virtual menunjukan nilai $\mathrm{F}=8,398$ dengan angka signifikan $(p)=0,005$. Karena angka signifikan $(p)$ lebih kecil dari alpha (tingkat signifikan) 0,05, maka hipotesis yang berbunyi terdapat perbedaan prestasi belajar kognitif siswa antara penggunaan laboratorium real dan gabungan real virtual pada pembelajaran fisika diterima. Artinya terdapat perbedaan prestasi belajar kognitif siswa antara penggunaan laboratorium real dan gabungan real virtual pada pembelajaran fisika.

Sikap ilmiah terhadapa prestasi belajar kognitif menunjukan nilai $\mathrm{F}=16,126$ dengan angka $\operatorname{signifikan}(\mathrm{p})=0,000$. Karena angka signifikan $(\mathrm{p})$ lebih kecil dari nilai alpha (tingkat signifikan) 0,05, maka hipotesis yang berbunyi terdapat perbedaan prestasi belajar kognitif antara siswa yang memiliki sikap ilmiah tinggi dan rendah diterima. Artinya terdapat perbedaan prestasi belajar kognitif antara siswa yang memiliki sikap ilmiah tinggi dan rendah. Tetapi untuk pengaruh interaksi penggunaan laboratorium dengan sikap ilmiah terhadap prestasi belajar kognitif secara statistik menunjukkan nilai $\mathrm{F}=0,334$ dengan angka signifikan $(p)=0,565$. Karena nilai probabilitasnya lebih besar dari nilai alpha (tingkat signifikan) 0,05, maka hipotesis yang berbunyai terdapat pengaruh interaksi penggunaan laboratorium dengan sikap ilmiah terhadap prestasi belajar kognitif di tolak. Artinya tidak terdapat pengaruh interaksi penggunaan laboratorium dengan sikap ilmiah terhadap prestasi belajar kognitif yang mengikuti pembelajaran fisika.

Hasil lain juga dapat dilihat pada tampilan data deskriptif yang ditunjukkan pada Gambar 1 .

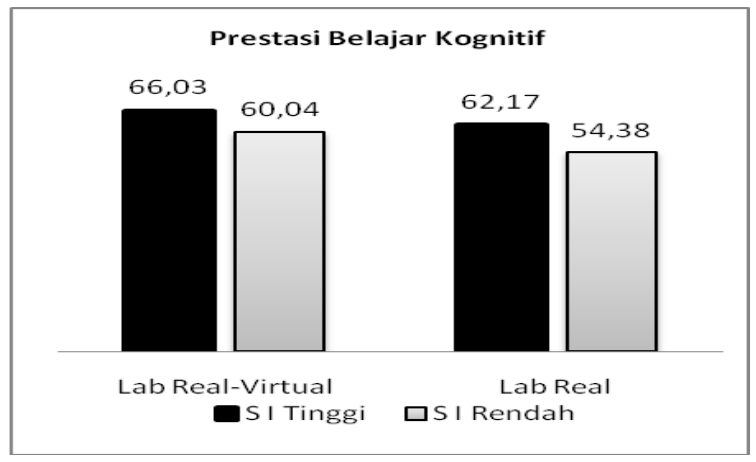

Gambar 1. Histogram Nilai rata-rata prestasi belajar kognitif Siswa
Berdasarkan histogram di atas, terlihat bahwa nilai rata-rata prestasi belajar kognitif siswa yang mendapatkan pembelajaran dengan menggunakan laboratorium gabungan real virtual lebih tinggi dibandingkan dengan yang menggunakan laboratorium real. Hal lain yang terlihat pada histogram di atas adalah siswa yang memiliki sikap ilmiah tinggi prestasi belajar kognitifnya lebih baik dibanding dengan siswa yang memiliki sikap ilmiah rendah, baik pada pembelajaran menggunakan laboratorium real maupun laboratorium gabungan real virtual. Hal ini menunjukkan bahwa penggunaan laboratorium gabungan real virtual dapat meningkatkan prestasi belajar kognitif siswa dibandingkan dengan penggunaan laboratorium real.

Dalam penelitian ini terungkap bahwa penggunaan laboratorium virtual yang dipadu dengan laboratorium real dapat meningkatkan prestasi belajar kognitif siswa. Karena pembelajaran menggunakan laboratorium virtual dapat membantu mempermudah pemahaman materi pembelajaran fisika dan dapat memvisualkan materi fisika yang tidak dapat divisualkan dengan menggunakan laboratorium real, misalnya aliran elektron dalam rangkaian listrik. Dikatakan Robeck dalam Isjoni (2008), menggunakan laboratorium virtual dapat mempercepat proses pemahaman materi pelajaran serta memperkuat keyakinan siswa akan kebenaran teori atau hukumhukum fisika yang telah dibuktikan dengan praktik menggunakan laboratorium real. Robeck juga mengatakan bahwa pembelajaran melalui pendekatan virtual banyak memberikan manfaat kepada siswa karena dapat meningkatkan (i) proses pemahaman sians (the us of science prosess skills), (ii) inkuiri sains (science inquiry), (iii) berfikir kritis (critical thinking), (iv) pemahaman konsep (conceptual understanding).

Hasil penelitian yang dilakukan oleh Nur Rohmadi (2007) pada pembelajaran fisika menunjukkan bahwa pembelajaran dengan menggunakan laboratorium virtual dapat meningkatkan prestasi belajar siswa. Sedangkan Tarno (2008) dalam penelitiannya terhadap siswa SMA, menunjukkan bahwa pembelajaran dengan menggunakan media laboratorium virtual lebih efektif daripada pembelajaran menggunakan media laboratorium real. Demikian pula menurut Agus Suyatna (2006) bahwa pembelajaran menggunakan simulasi praktikum (laboratorium virtual) dapat 
memberikan hasil yang lebih baik dibandingkan dengan praktikum tradisional (laboratorium real).

Hal lain dalam penelitian ini terungkap bahwa siswa yang memiliki sikap ilmiah tinggi cenderung prestasi kognitifnya lebih baik dibanding dengan siswa yang sikap ilmianya rendah. Hasil penelitian yang dilakukan oleh Duri Dyah Purwaningsih (2007), pada pembelajaran matematika menunjukkan bahwa ada pengaruh yang positif sikap ilmiah terhadap hasil belajar siswa. Sedangkan Prima Emirianti (2005), dalam penelitiannya terhadap mahasiswa teknik sipil, menunjukkan bahwa sikap ilmiah dan konstruktif mahasiswa memberikan pengaruh yang positif meningkatkan prestasi belajar. Dari hasil penelitian ini menunjukkan bahwa sikap ilmiah sangat berpengaruh terhadap prestasi belajar siswa atau mahasiswa.

Dalam pelajaran fisika, sikap ilmiah ini tercermin dengan keingintahuan siswa untuk mengetahui darimana suatu konsep, hukum atau rumus fisika itu diperoleh, dan bagaimana konsep, hukum atau rumus tersebut dapat diterapkan dalam kehidupan. Selain keingintahuan siswa mempelajari sesuatu, sikap ilmiah siswa juga tercermin dari tindakan kejujuran siswa dalam dalam belajar. Misalnya dalam mengerjakan suatu soal siswa selalu berusaha menyelesaikan sendiri, tanpa harus menyontek pekerjaan milik temannya. Kekritisan siswa dalam mempelajari sesuatu, juga merupakan bagian sikap ilmiah siswa. Siswa dalam hal ini akan berusaha mengevaluasi pekerjaan. Siswa juga berusaha untuk mengkritisi jawaban yang dikerjakannya maupun yang dikerjakan temannya.

Sikap ilmiah siswa yang berasal dari keingintahuan siswa, kejujuran siswa, serta sikap kekritisan siswa dalam mempelajari suatu pelajaran, khususnya pelajaran fisika menjadikan siswa dalam belajar fisika akan bersungguhsungguh tanpa ada paksaan dari pihak lain. Sikap ilimiah siswa inilah siswa akan menyenangi pelajaran, sehingga hasil belajar yang diperoleh siswa akan baik.

Untuk itu sangat diharapkan agar para guru dapat memberikan stimulus atau pengaruh agar sikap ilmiah yang ada pada setiap peserta didik dapat tumbah dan berkembang, karena sikap ilmiah yang terdapat pada diri siswa merupakan watak perilaku manusia yang tidak dapat dipaksakan untuk bertindak dalam mempelajari sesuatu melainkan muncul dari diri siswa itu sendiri karena adanya rangsangan dari lingkungan, sehingga mendorong siswa untuk mencapai tujuan belajar yaitu hasil yang tinggi dan maksimal (Andersen, 1981).

Dalam penelitian ini juga terungkap bahwa interaksi antara pembelajaran menggunakan laboratorium dengan sikap ilmiah, berdasarkan analisis varians dengan derajad kebebasan 1:98 dan taraf signifikansi 5\%, menunjukkan bahwa interaksi antara penggunaan laboratorium dengan sikap ilmiah tidak berpengaruh terhadap prestasi belajar, tetapi secara deskriptif rata-rata prestasi belajar kognitif siswa menunjukkan bahwa interaksi penggunaan laboratorium gabungan real virtual dengan sikap ilmiah tinggi $(66,04)$ lebih unggul dibandingkan penggunaan laboratorium real dengan sikap ilmiah tinggi $(62,17)$ dan interaksi penggunaan laboratorium gabungan real virtual dengan sikap ilmiah rendah $(60,04)$ lebih unggul dibandingkan penggunaan laboratorium real dengan sikap ilmiah rendah $(54,38)$.

Hasil ini memberikan makna bahwa peningkatan prestasi belajar kognitif siswa dapat dipengaruhi oleh penggunaan laboratorium, sikap ilmiah maupun interaksi keduanya terutama penggunaan laboratorium gabungan real virtual dengan sikap ilmiah tinggi siswa. Dengan demikian interaksi penggunaan laboratorium yang dengan sikap ilmiah dapat meningkatkan prestasi belajar siswa.

\section{Kesimpulan}

Berdasarkan hasil analisis data penelitian, dapat ditarik kesimpulan bahwa: 1) Terdapat perbedaan prestasi belajar (kognitif dan psikomotorik) siswa antara pembelajaran menggunakan laboratorium real dan laboratorium gabungan real virtual pada fisika materi listrik dinamis. Pembelajaran menggunakan laboratorium gabungan real virtual memberikan hasil yang lebih baik daripada pembelajaran menggunakan laboratorium real. 2) Tidak terdapat perbedaan prestasi belajar afektif siswa antara penggunaan laboratorium real dan laboratorium gabungan real virtual. 3) Terdapat perbedaan prestasi belajar (kognitif, psikomotorik dan afektif) antara siswa yang memiliki sikap ilmiah tinggi dan sikap ilmiah rendah pada pembelajaran fisika materi listrik dinamis. Siswa yang memiliki sikap ilmiah tinggi 
memilki prestasi belajar (kognitif, psikomotorik dan afeksi) lebih baik daripada siswa yang memiliki sikap ilmiah rendah. 4)Tidak terdapat pengaruh interaksi antara penggunaan laboratorium (real dan gabungan real virtual) dengan sikap ilmiah (tinggi dan rendah) terhadap prestasi belajar (kognitif, psikomotorik dan afektif) siswa pada pembelajaran fisika materi listrik dinamis. 5) Untuk meningkatkan prestasi belajar, siswa yang memiliki sikap ilmiah tinggi dapat diberikan pembelajaran dengan menggunakan laboratorium real maupun laboratorium gabungan real virtual, sedangkan siswa yang memiliki sikap ilmiah rendah sebaiknya menggunakan laboratorium gabungan real virtual.

Hasil penelitian ini memberikan gambaran yang jelas tentang adanya pengaruh penggunaan laboratorium terhadap prestasi belajar siswa pada prestasi belajar kognitif dan psikomotorik, demikian juga sikap ilmiah yang dimiliki siswa juga sangat berpengaruh terhadap prestasi belajar (kognitif, psikomotorik dan afektif).

\section{Saran}

Dalam rangka peningkatan kualitas pendidikan khusus dalam pendidikan/pembelajaran fisika, berdasarkan kesimpulan di atas menyarankan sebagai berikut:

1. Saran kepada para guru/pendidik: (a) dalam pembelajaran fisika apabila mempunyai laboratorium real hendaknya digunakan, apabila dalam penggunaanya banyak menyita waktu, maka penggunaanya dapat dipadukan dengan laboratorium virtual, (b) guru hendaknya pandai dalam memilih alat atau bahan yang tepat dalam pembelajaran fisika, (c) bagi sekolah yang belum memiliki laboratorium real dapat menggunakan laboratorium virtual untuk melakukan eksperimen.

2. Dalam proses pembelajaran, guru hendaknya banyak melibatkan siswa dan memberikan stimulus kepada siswa agar timbul sikap positip terhadap obyek yang sedang dipelajari, karena dengan sikap positip siswa yang tinggi dapat meningkatkan prestasi belajarnya.

3. Kepada kepala sekolah/madrasah diharapkan: (a) mendorong kepada guru-guru, bahwa dalam pembelajaran fisika hendaknya dilaksanakan dengan media laboratorium, (b) memberikan kesempatan kepada guru untuk memilih metode dan model pembelajaran yang tepat sesuai dengan kondisi siswa dan sekolah/madrasah yang ada.

4. Saran kepada pemegang otoritas pendidikan di sekolah/madrasah, agar mensosialisasika dan membuat kebijakan bahwa komputer dapat dimanfaatkan sebagai media pembelajaran kususnya sebagai laboratorium virtual.

5. Kepada orang tua, hendaknya dapat berpatisipasi aktif sebagai motivator dan fasilitator dalam melaksanaan pendidikan di sekolah/madarasah.

\section{Daftar Pustaka}

Andersen, Lorin.w. 1981. Assessing Affective Characteristic in the School. Boston. Allyn and Bacon.

Depdiknas. 2008. Perangkat Penilaian Kurikulum Tingkat Satuan Pendidikan Sekolah Menengah Atas. Jakarta. Direktorat Jendral Menejemen Pendidikan Dasar dan Menengah.

Emirianti, Prima. 2005. Pengaruh Sikap Ilmiah dan Konstruktif Mahasiswa pada Waktu perkuliahan Terhadap Prestasi Belajar Struktur Kayau Mahasiswa Jurusan Teknik Sipil Fakultas Teknik Universitas Negeri Semarang. Tesis Unesa.

Fatika, Sandra. 1987. Ilmu Alamiah Dasar. UNS Pres. Surakarta

Isjoni dan Arif, Mohd. 2008. Pembelajaran Virtual Perpaduan Indonesia - Malaysia. Yogyakarta. Pustaka Pelajar.

Purwaningsih, Dyah Dwi. 2007. Pengaruh Sikap Ilmiah Terhadap Hasil Belajar Materi Bangun ruang Kelas VIII SMP Negeri 16 Semarang. Skripsi . FPMIPA Unerversitas Negeri Semarang.

Roestiyah, NK. 1991. Strategi Belajar Mengajar. Jakarta. Rineka Cipta.

Rohmadi, Nur (2007). Pengaruh Pembelajaran Fisika Menggunakan Laboratorium Virtual Terhadap Prestasi Belajar Ditinjau Dari Kemampuan Awal Siswa. Tesis. UNS

Slameto. 2010. Belajar dan Faktor yang mempengaruhinya. Jakarta: Rineka Cipta. 
Suyatna, Agus. 2006. Pemanfaatan Laboratorium Fisika Virtual. Jurnal Program Studi Pendidikan Fisika. Edisi Desember 2006. FKIP Unila. Lampung

Tarno. 2008. Pembelajaran Fisika Metode Eksperimen Menggunakan Laboratorium Riil dan Virtual Ditinjau dari Kemampuan Berpikir dan Kreativitas Peserta Didik. Tesis UNS. 